\title{
Silibinin induces apoptosis via calpain-dependent AIF nuclear translocation in U87MG human glioma cell death
}

\author{
Ji C Jeong ${ }^{1}$, Won Y Shin ${ }^{1}$, Thae H Kim², Chae H Kwon², Jae H Kim², Yong K Kim² and Ki H Kim
}

\begin{abstract}
Background: Silibinin, a natural polyphenolic flavonoid, has been reported to induce cell death in various cancer cell types. However, the molecular mechanism is not clearly defined. Our previous study showed that silibinin induces glioma cell death and its effect was effectively prevented by calpain inhibitor. The present study was therefore undertaken to examine the role of calpain in the silibinin-induced glioma cell death.
\end{abstract}

Methods: U87MG cells were grown on well tissue culture plates and cell viability was measured by MTT assay. ROS generation and $\Delta \psi_{m}$ were estimated using the fluorescence dyes. PKC activation and Bax expression were measured by Western blot analysis. AlF nuclear translocation was determined by Western blot and immunocytochemistry.

Results: Silibinin induced activation of calpain, which was blocked by EGTA and the calpain inhibitor Z-Leu-Leu$\mathrm{CHO}$. Silibinin caused ROS generation and its effect was inhibited by calpain inhibitor, the general PKC inhibitor GF 109203X, the specific $\mathrm{PKC}_{\delta}$ inhibitor rottlerin, and catalase. Silibinin-induce cell death was blocked by calpain inhibitor and PKC inhibitors. Silibinin-induced $\mathrm{PKC}_{\delta}$ activation and disruption of $\Delta \psi_{\mathrm{m}}$ were prevented by the calpain inhibitor. Silibinin induced AIF nuclear translocation and its effect was prevented by calpain inhibitor. Transfection of vector expressing microRNA of AIF prevented the silibinin-induced cell death.

Conclusions: Silibinin induces apoptotic cell death through a calpain-dependent mechanism involving PKC, ROS, and AIF nuclear translocation in U87MG human glioma cells.

\section{Background}

Glioblastoma is the most lethal and frequent primary brain tumors [1]. It is comprised of poorly differentiated heterogeneous neoplastic astrocytes with aggressive proliferation and highly invasive properties. After diagnosis of glioblastoma, the median survival time of 9-12 months has remained unchanged despite aggressive treatment including surgery, radiation, and chemotherapy $[2,3]$. Thus, new effective strategies for controlling glioblastoma are required. Because glioblastoma cells avoid differentiation and apoptosis, the induction of differentiation and apoptosis in glioblastoma cells may be considered as a potential treatment strategy.

\footnotetext{
* Correspondence: ghkim@pusan.ac.kr

${ }^{3}$ Department of Obstetrics and Gynecology, College of Medicine, Pusan National University, and Medical Research Institute and Pusan Cancer Center, Pusan National University Hospital, Pusan, 602-739, Korea

Full list of author information is available at the end of the article
}

Silibinin, a natural polyphenolic flavonoid, is a major bioactive component of silymarin which is isolated from the plant milk thistle (Silybum marianum), and has been extensively used for its hepatoprotective effects in Asia and Europe. It has been reported that silibinin has anticancer activities in various cancers including prostate cancer in both in vitro and in vivo models [4-7]. Recently, we observed that silibinin induces apoptosis through $\mathrm{Ca}^{2+} / \mathrm{ROS}$-dependent mechanism in human glioma cells [8]. The study showed that silibinin-induced cell death was prevented by calpain inhibitor, suggesting involvement of calpain activation in apoptosis induced by silibinin. Therefore, the present study was undertaken to examine role of calpain in the sililbinin-induced glioma cell death. The present study demonstrated that silibinin induces human glioma cell death via a calpaindependent AIF nuclear translocation involving ROS and PKC.

\section{C) Biomed Central}




\section{Materials and methods Reagents}

Silibinin, GF 109203X, rottlerin, catalase, MTT, propidium iodide was purchased from Sigma-Aldrich Chemical (St. Louis, MO, USA). Z-Leu-Leu-CHO was purchased from BIOMOL International LP (Plymouth Meeting, PA, USA). DCFH-DA and $\mathrm{DiOC}_{6}(3)$ were obtained from Molecular Probes (Eugene, OR, USA). Antibodies were obtained from Cell Signaling Technology Inc. (Beverly, MA, USA). All other chemicals were of the highest commercial grade available.

\section{Cell culture}

U87MG cells were obtained from the American Type Culture Collection (Rockville, MD, USA) and maintained by serial passages in $75-\mathrm{cm}^{2}$ culture flasks (Costar, Cambridge, MA, USA). The cells were grown in Dulbecco's modified Eagle's medium (DMEM, Gibco BRL, Invitrogen, Carsbad, CA, USA) containing 10\% heat inactivated fetal bovine serum (HyClone, Logan, UT, USA) at $37^{\circ} \mathrm{C}$ in humidified $95 \%$ air $/ 5 \% \mathrm{CO}_{2}$ incubator. When the cultures reached confluence, subculture was prepared using a $0.02 \%$ EDTA- $0.05 \%$ trypsin solution. The cells were grown on well tissue culture plates and used 1-2 days after plating when a confluent monolayer culture was achieved. Unless otherwise stated, cells were treated with silibinin in serum-free medium. Test reagents were added to the medium $30 \mathrm{~min}$ before silibinin exposure.

\section{Measurement of cell viability}

Cell viability was evaluated using a MTT assay [9]. Culture medium containing $0.5 \mathrm{mg} / \mathrm{ml}$ of MTT was added to each well. The cells were incubated for $2 \mathrm{~h}$ at $37^{\circ} \mathrm{C}$, the supernatant was removed and the formed formazan crystals in viable cells were solubilized with $0.11 \mathrm{ml}$ of dimethyl sulfoxide. A $0.1 \mathrm{ml}$ aliquot of each sample was then translated to 96-well plates and the absorbance of each well was measured at $550 \mathrm{~nm}$ with ELISA Reader (FLUOstar OPTIMA, BMG LABTECH, Offenburg, Germany). Data were expressed as a percentage of control measured in the absence of silibinin.

\section{Measurement of calpain activity}

Calpain activity was measured by calpain assay kit (BioVision Research Products, CA, USA) according to the manufacturer's instructions. Cells were grown in 6-well plates and were treated as indicated. Detached cells from the bottom of culture plates by trypsin were pelleted by centrifugation and washed with phosphate-buffered saline (PBS). The pellet were suspended in extraction buffer and incubated on ice for $20 \mathrm{~min}$ then centrifuged at $10,000 \times \mathrm{g}$ for $10 \mathrm{~min}$ at $4^{\circ} \mathrm{C}$. The supernatant represented the cytosolic protein. Add $10 \mu \mathrm{l}$ of $10 \times$ reaction buffer and $5 \mu \mathrm{l}$ of calpain substrate, Ac-LLY-AFC, to each assay. Incubate at $37^{\circ} \mathrm{C}$ for $1 \mathrm{~h}$ in the dark. After incubation, production of free AFC was fluorometrically measured suing a Victor 3 Multilabel Counter with an excitation filter of $400 \mathrm{~nm}$ and an emission filter of 505 nm (PerkinElmer, Boston, MA, USA).

\section{Measurement of reactive oxygen species (ROS)}

The intracellular generation of ROS was measured using DCFH-DA. The nonfluorescent ester penetrates into the cells and is hydrolyzed to DCFH by the cellular esterases. The probe (DCFH) is rapidly oxidized to the highly fluorescent compound DCF in the presence of cellular peroxidase and ROS such as hydrogen peroxide or fatty acid peroxides. Cells cultured in 24-well plate were preincubated in the culture medium with $30 \mu \mathrm{M}$ DCFH-DA for $1 \mathrm{~h}$ at $37^{\circ} \mathrm{C}$. After the preincubation, the cells were exposed to $30 \mu \mathrm{M}$ silibinin for various times. Changes in DCF fluorescence was assayed using FACSort Becton Dickinson Flow Cytometer (Becton-Dickinson Bioscience, San Jose, CA, USA) and data were analyzed with CELLQuest Software.

\section{Measurement of ${ }^{\Delta} \boldsymbol{\psi}_{\mathrm{m}}$}

The ${ }^{\Delta} \psi_{\mathrm{m}}$ was measured with $\operatorname{DiOC}_{6}(3)$, a fluorochrome that is incorporated into cells depending upon the mitochondrial membrane potential [10]. Loss in $\mathrm{DiOC}_{6}(3)$ staining indicates disruption of the ${ }^{\Delta} \psi_{\mathrm{m}}$. Cells were stained with $\mathrm{DiOC}_{6}(3)$ at a final concentration of $50 \mathrm{nM}$ for $20 \mathrm{~min}$ at $37^{\circ} \mathrm{C}$ in the dark. Cells were washed and resuspended in Hank's balanced salts solution containing $\mathrm{Ca}^{2+}$ and $\mathrm{Mg}^{2+}$. The fluorescence intensity was analyzed with a FACScan flow cytometer using the fluorescence signal 1 channel.

\section{Western blot analysis}

Cells were harvest at various times after silibinin treatment and disrupted in lysis buffer (1\% Triton X-100, $1 \mathrm{mM}$ EGTA, 1 mM EDTA, 10 mM Tris-HCl, pH 7.4). Cell debris was removed by centrifugation at $10,000 \mathrm{~g}$ for $10 \mathrm{~min}$ at $4^{\circ} \mathrm{C}$. The resulting supernatants were resolved on a $10 \%$ SDS-PAGE under denatured reducing conditions and transferred to nitrocellulose membranes. The membranes were blocked with $5 \%$ non-fat dried milk at room temperature for $30 \mathrm{~min}$ and incubated with different primary antibodies. The membranes were washed and incubated with horseradish peroxidase-conjugated secondary antibodies. The signal was visualized using an enhanced chemiluminescence (Amersham, Buckinghamshire, UK).

\section{Measurement of AIF nuclear translocation}

Cells were harvested and washed twice with PBS. The cells were incubated with extraction buffer (10 mM Hepes, 
$250 \mathrm{mM}$ sucrose, $10 \mathrm{mM} \mathrm{KCl}, 1.5 \mathrm{mM} \mathrm{MgCl}_{2}, 1 \mathrm{mM}$ EDTA, $1 \mathrm{mM}$ EGTA, 0.05\% digitonin, and $1 \mathrm{mM}$ phenylmethylsulfonyl fluoride) at $4^{\circ} \mathrm{C}$ for $10 \mathrm{~min}$, then centrifuged at $100000 \mathrm{~g}$ for $10 \mathrm{~min}$ at $4^{\circ} \mathrm{C}$. The supernatant cytosolic protein was removed and the pellet was incubated in the nuclear extraction buffer $(350 \mathrm{mM} \mathrm{NaCl}, 1$ mM EGTA, 1 mM EDTA, $10 \mathrm{mM}$ Tris- $\mathrm{HCl}, \mathrm{pH}$ 7.4, and protease inhibitors) at $4^{\circ} \mathrm{C}$ for $10 \mathrm{~min}$, then centrifuged at $10000 \mathrm{~g}$ for $10 \mathrm{~min}$ at $4^{\circ} \mathrm{C}$. Proteins were loaded onto a $12 \%$ SDS-polyacrylamide gels and transferred to nitrocellulose membranes. After blocking in $5 \%$ non-fat dried milk at room temperature for $30 \mathrm{~min}$, membranes were probed with rabbit polyclonal anti-AIF antibody, followed by horseradish peroxidase-conjugated secondary antibodies. Bands were visualized using the ECL detection system (Amersham, Buckinghamshire, UK).

AIF nuclear translocation was further confirmed by immunofluorescence analysis. Cells were cultured on glass coverslips and treated with silibinin. Cells were washed twice with PBS, fixed with $4 \%$ paraformadehyde in PBS for $10 \mathrm{~min}$, permeabilized with $0.5 \%$ Triton X100 in PBS for 10 min. After washing twice with PBS, cells were blocked with $8 \%$ BSA in Tris-buffered saline Triton X-100 (TBST). Cells were incubated with rabbit polyclonal anti-AIF overnight $4{ }^{\circ} \mathrm{C}$ and washed twice with TBST. Cells were incubated with FITC-conjugated secondary antibody (Jackson ImmunoResearch Laboratories, PA, USA) for $1 \mathrm{~h}$, and the nuclei were counterstained with propidium iodide to ascertain AIF unclear localization. Cell were washed twice and visualized by using the confocal microscope (Leica, Wetzlar, Germany).

\section{RNA interference (RNAi)}

For AIF targeting, we used The BLOCK-iT'TM Pol miR RNAi Expression Vector Kits (Invitrogen, Carlsbad, CA, USA) to facilitate the expression of microRNA (miRNA). miRNA sequences for AIF were designed using online software (BLOCK-iT RNAi Designer from Invitrogen). The target sequence was 5'-GTGCCTATGCCTACAAGACTA-3'. This single-stranded oligonucleotide generated a double-stranded oligonucleotide, which instructed into pcDNA ${ }^{\mathrm{TM}}$ 6.2-GW/EmGFP-miR vector. This vector contains EmGFP that allow identifying of the transfection efficiency using fluorescence microscopy. The construct $\mathrm{pcDNA}^{\mathrm{TM}}$ 6.2-GW/EmGFP-miR-LacZ was used as a control. Cells were transiently transfected with these plasmids using lipofectamine (Invitrogen).

\section{Statistical analysis}

The data are expressed as means \pm SEM and the difference between two groups was evaluated using Student's $t$-test. Multiple group comparison was done using oneway analysis of variance followed by the Tukey post hoc test. A probability level of 0.05 was used to establish significance.

\section{Results and Discussion}

Effect of calpain inhibitor on silibinin-induced cell death Calpains are cytosolic $\mathrm{Ca}^{2+}$-activated neutral cysteine proteases and ubiquitously distributed in all animal cells, which play a critical role in regulating cell viability $[11,12]$. Accumulating evidence suggests that calpain activation may contribute to cell death in certain cell types including thymocytes, monocytes, cardiomyocytes, and neuronal cells [13]. Since our previous study showed that the calpain inhibitor Z-Leu-Leu-CHO at $0.5 \mu \mathrm{M}$ significantly protected effectively against the silibinin-induced cell death [8], we observed in the present study the dose-dependency of the inhibitor effect. The results showed that the calpain inhibitor exerted protective effect against the silibinin-induced cell death in a dose-dependent manner with maximum potency at 0.5 $1 \mu \mathrm{M}$ (Figure 1A). Silibinin also induced calpain activation, which was blocked by EGTA and calpain inhibitor (Figure 1B). These results indicate that calpain activation plays a critical role in the silibinin-induced cell death in human glioma cells.

\section{Role of calpain and protein kinase C (PKC) activation in ROS generation and cell death induced by silibinin}

The silibinin-induced cell death was associated with ROS generation mediated by intracellular $\mathrm{Ca}^{2+}[8]$. To determine therefore whether ROS production by silibinin is attributed to calpain activation, cells were exposed to silibinin in the presence of calpain inhibitor and ROS generation was measured. As shown in Figure 2A, the silibinin-induced ROS generation was blocked by the calpain inhibitor with potency similar to that of catalase.

PKCs are a family of serine/threonine kinases which are involved in tumor formation and progression [14]. PKC isoforms cooperate or exert opposite effects on the process of apoptosis [15,16]. PKC isoforms such as PKC $\alpha, \varepsilon$, and $\xi$ inhibit apoptosis, whereas $\mathrm{PKC}_{\delta}$ is involved in the process of apoptosis $[16,17]$. Although previous studies have shown that flavonoids can induce activation of PKC $[18,19]$, it is unclear whether PKC is involved in the signaling cascade of silibinin-induced cell death. Although PKCs are activated by ROS $[20,21]$, it has been reported that PKC activation can also cause ROS generation [22,23]. Therefore, we examined involvement of PKC in the silibinin-induced ROS generation. The general PKC inhibitor GF 109203X and the selective $\mathrm{PKC}_{\delta}$ inhibitor rottlerin blocked the ROS generation (Figure 2A). The silibinininduced cell death was also prevented by the general PKC inhibitor GF 109203X and rottlerin (Figure 2B), indicating that silibinin induces ROS generation and cell death through PKC activation. We next examined whether 


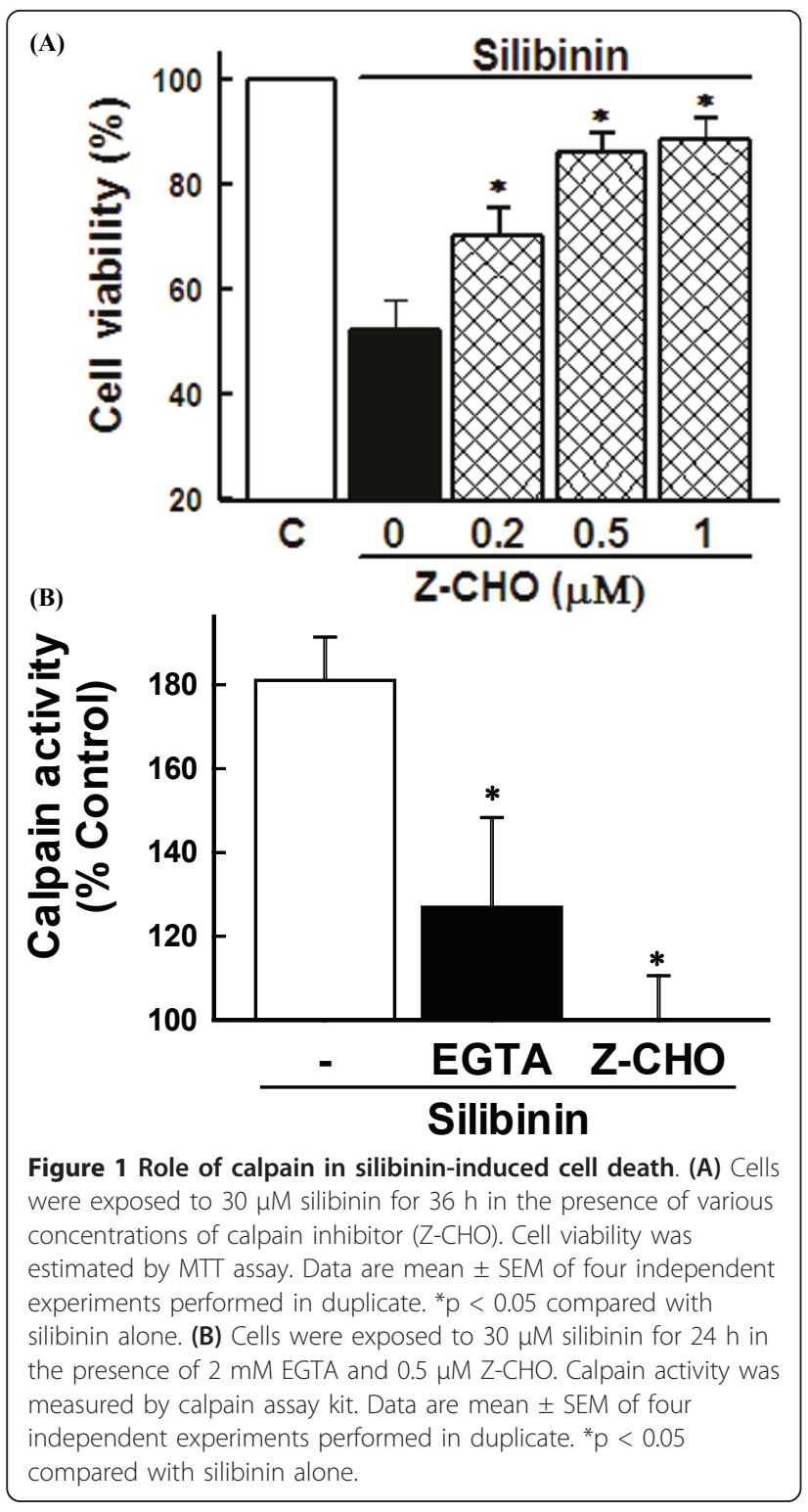

silibinin induces $\mathrm{PKC}_{\delta}$ phosphorylation, an index of $\mathrm{PKC}_{\delta}$ activation. Silibinin induced a transient phosphorylation of $\mathrm{PKC}_{\delta}$ after $10 \mathrm{~min}$ of treatment, which was inhibited by treatment of calpain inhibitor (Figure $2 \mathrm{C}$ and $2 \mathrm{D}$ ), suggesting that $\mathrm{PKC}_{\delta}$ may be a downstream of calpain in the silibinin-induced cell death. Similar results are reported in human U-937 leukemia cells in which the flavonoid wogonin induces cell arrest through $\mathrm{PKC}_{\delta}$ activation [18].

\section{Role of Bax expression and mitochondria in silibinin- induced cell death}

Since numerous death signals converge on mitochondria through the activation of pro-apoptotic members of the Bcl-2 family such as Bax [24], calpain activation may induce the silibinin-induced cell death through a Bax-
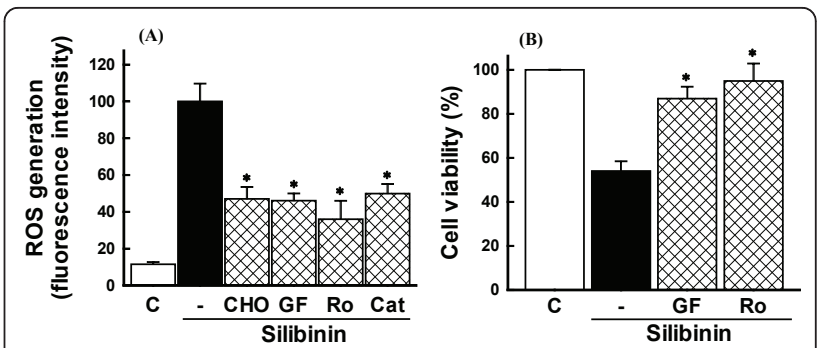

(C)
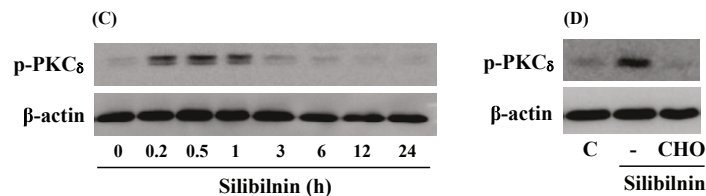

Figure 2 Role of calpain and PKC in ROS generation and cell death induced by silibinin. (A) Effect of inhibitors of calpain and PKC on silibinin-induced ROS generation. Cells were exposed to 30 $\mu \mathrm{M}$ silibinin in the presence or absence of $0.5 \mu \mathrm{M}$ calpain inhibitor (CHO), 1 MM GF 109203X (GF), 1 MM rottlerin (Ro), and 800 units/ml catalase (Cat) and ROS generation was estimated by measuring changes in DCF fluorescence using FACS analysis. Data are mean \pm SEM of five independent experiments performed in duplicate. ${ }^{*} p<$ 0.05 compared with silibinin alone. (B) Effect of PKC inhibitors on silibinin-induced cell death. Cells were exposed to $30 \mu \mathrm{M}$ silibinin in the presence or absence of $1 \mu \mathrm{M}$ GF 109203X (GF) and $1 \mu \mathrm{M}$ rottlerin (Ro) and cell viability was measured by MTT assay. Data are mean \pm SEM of four independent experiments performed in duplicate. ${ }^{*} p<0.05$ compared with silibinin alone. (C) Effect of silibinin on $\mathrm{PKC}_{\delta}$ activation. Cells were exposed to $30 \mu \mathrm{M}$ silibinin for various times and $\mathrm{PKC}_{\delta}$ phosphorylation was estimated by Western blot analysis. (D) Effect of calpain inhibitor on $\mathrm{PKC}_{\delta}$ phosphorylation. Cells were exposed to $30 \mu \mathrm{M}$ silibinin for $10 \mathrm{~min}$ in the presence or absence of $0.5 \mu \mathrm{M}$ calpain inhibitor $(\mathrm{CHO})$ and $\mathrm{PKC}_{\delta}$ phosphorylation was estimated by Western blot analysis.

dependent pathway. To test this possibility, the effect of silibinin on Bax expression was examined. Silibinin increased Bax expression after $3 \mathrm{~h}$ of treatment, which was blocked by the calpain inhibitor (Figure 3).

The increase in Bax expression may cause disruption of $\Delta \psi_{\mathrm{m}}$ to induce cell death. To test the possibility, cells were exposed to silibinin and the $\Delta \psi_{\mathrm{m}}$ was measured using the fluorescence dye. After silibinin treatment, disruption of $\Delta \psi_{\mathrm{m}}$ was observed as evidenced by an increase in the proportion of cells with lower fluorescence intensity (Figure 4A). The reduction in ${ }^{\Delta} \psi_{\mathrm{m}}$ was observed after $3 \mathrm{~h}$ of silibinin treatment and remained unchanged even after $12 \mathrm{~h}$ (Figure $4 \mathrm{~B}$ ).

Disruption of $\Delta \psi_{\mathrm{m}}$ by silibinin may be associated with ROS generation. To test the possibility, cells were exposed to silibinin in the presence of the antioxidant catalase and $\Delta_{\psi_{\mathrm{m}}}$ was measured. Figure $4 \mathrm{C}$ shows that the silibinin-induced reduction in ${ }^{\Delta} \psi_{\mathrm{m}}$ was blocked by catalase, suggesting that the $\Delta \psi_{\mathrm{m}}$ disruption by silibinin is mediated by ROS generation. 




As shown above, since the silibinin-induced ROS generation was blocked by inhibitors of calpain and PKC, the silibinin-induced disruption of $\Delta \psi_{\mathrm{m}}$ would be prevented by these inhibitors. As expected, the reduction in $\Delta_{\mathrm{m}}$ was blocked by Z-Leu-Leu-CHO, GF 109203X, and rottlerin, with similar potency to that by catalase (Figure 4C).

Role of AIF nuclear translocation in silibinin-induced cell death

The mitochondrial apoptotic pathway is initiated by the cytosolic release of mitochondrial intermembrane space proteins that can trigger either caspase-activation or caspase-independent apoptotic pathways [25,26]. Mitochondrial proteins that cause caspase-dependent

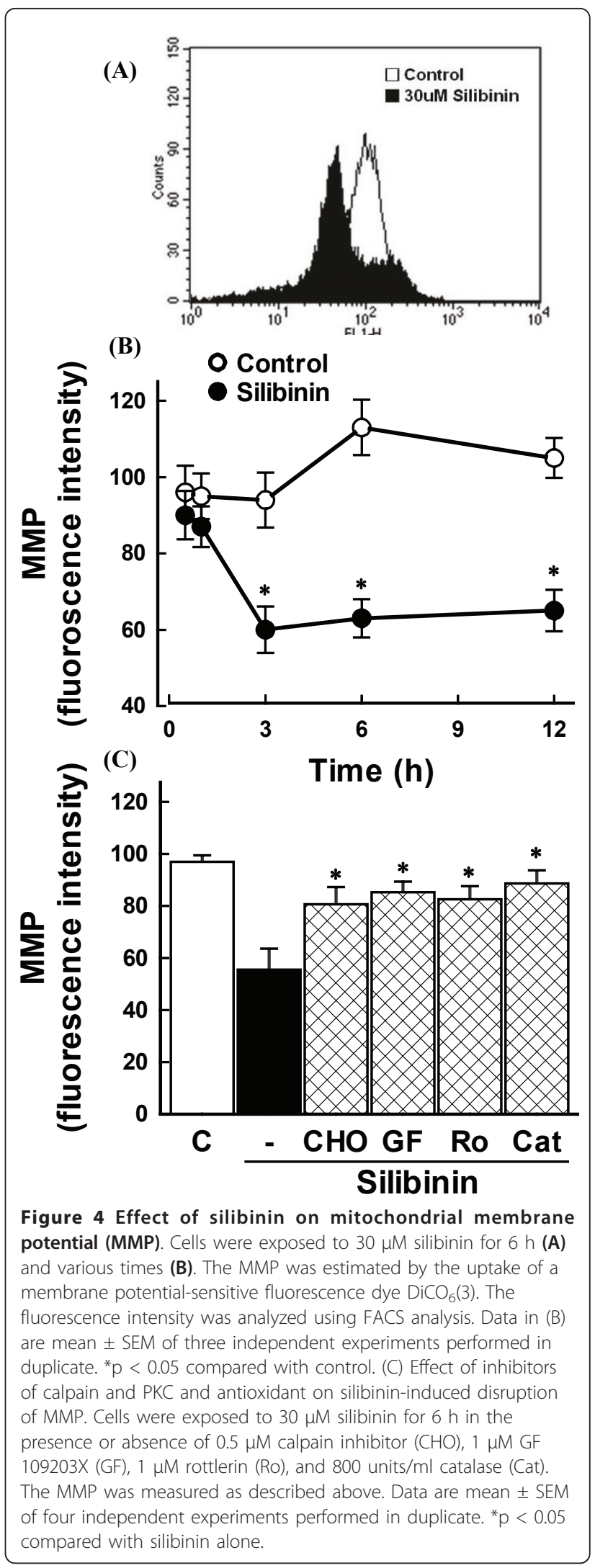







cell death include cytochrome c which triggers caspase- 9 activation through Apaf-1. The activated caspase-9 then activates the downstream caspase- 3 [26-28]. Mitochondria have also been reported to contain AIF, which can cleave directly DNA and intracellular substrates when released into the cytosol. During apoptosis, AIF translocates into the nucleus where it causes oligonucleosomal DNA fragmentation [29,30]. The present study showed that silibinin causes AIF nuclear translocation, which was inhibited by the calpain inhibitor (Figure 5A and 5B). To determine if silibinin induced cell death through AIF nuclear translocation, effect of silibinin on the cell death in cells transfected with AIF mi-RNA was measured. Transfection of AIF mi-RNA was decreased AIF protein levels (Figure 5C) and effectively prevented the silibinin-induced cell death (Figure 5D). These data suggest that calpain activation induces AIF-dependent cell death in silibinin-treated cells. This is the first report showing involvement of calpain-dependent AIF nuclear translocation in the silibinin-induced glioma cell death.

\section{Conclusion}

The present study demonstrated that silibinin induces apoptosis through AIF nuclear translocation mediated by a calpain-dependent pathway in U87MG human glioma cells. This pathway involves PKC activation and ROS generation. These data suggest that silibinin may be considered a potential candidate in prevention and treatment of human malignant gliomas.

\section{List of abbreviations}

AIF: apoptosis-inducing factor; DCF: 2',7'-dichlorofluorescein; DCFH-DA: 2',7'dichlorofluorescein diacetate; $\operatorname{DiOC}_{6}(3)$ : 3,3'-dihexyloxacarbocyamide; MTT: 3 [4,5-dimethylthiazol-2-yl]-2,5-diphenyltetrazolium bromide; PBS: phosphate buffer solution; PKC: protein kinase C; ROS: reactive oxygen species; $\Delta \psi_{\mathrm{m}}$ : mitochondrial membrane potential.

\section{Acknowledgements}

This research was supported by Basic Science Research program through the National Research Foundation of Korea (NRF) funded by the Ministry of Education, Science and Technology (2010-0003690) and a grant from the National R\&D Program for Cancer Control, Ministry for Health, Welfare and Family affairs (0920050).

\section{Author details}

${ }^{1}$ Department of Oriental Medicine, Dongguk University, Kyung Ju, 780-714, Korea. ${ }^{2}$ Department of Physiology, College of Medicine, Pusan National University, Yangsan, Gyeongsangnam-do, 626-770, Korea. ${ }^{3}$ Department of Obstetrics and Gynecology, College of Medicine, Pusan National University, and Medical Research Institute and Pusan Cancer Center, Pusan National University Hospital, Pusan, 602-739, Korea.

\section{Authors' contributions}

JJ carried out cell viability and apoptosis assay, participated in drafted the manuscript. WS and TK carried out mitochondrial membrane potential, ROS generation, and statistical analyses. CK and YK carried out Western blot, calpain activity, and AIF nuclear translocation. KK and JK participated in experiment design and the draft preparation. All authors read and approved the final manuscript.

\section{Competing interests}

The authors declare that they have no competing interests.

Received: 6 January 2011 Accepted: 19 April 2011

Published: 19 April 2011

\section{References}

1. Ohgaki $H$, Kleihues P: Population-based studies on incidence, survival rates, and genetic alterations in astrocytic and oligodendroglial gliomas. J Neuropathol Exp Neurol 2005, 64(6):479-489.

2. DeAngelis LM: Brain tumors. N Engl J Med 2001, 344(2):114-123.

3. Sanai N, Alvarez-Buylla A, Berger MS: Neural stem cells and the origin of gliomas. N Engl J Med 2005, 353(8):811-822.

4. Singh RP, Gu M, Agarwal R: Silibinin inhibits colorectal cancer growth by inhibiting tumor cell proliferation and angiogenesis. Cancer Res 2008, 68(6):2043-2050.

5. Singh RP, Mallikarjuna GU, Sharma G, Dhanalakshmi S, Tyagi AK, Chan DC, Agarwal C, Agarwal R: Oral silibinin inhibits lung tumor growth in athymic nude mice and forms a novel chemocombination with doxorubicin targeting nuclear factor kappaB-mediated inducible chemoresistance. Clin Cancer Res 2004, 10(24):8641-8647.

6. Ramasamy K, Agarwal R: Multitargeted therapy of cancer by silymarin. Cancer Lett 2008, 269(352-362.

7. Kaur M, Agarwal R: Silymarin and epithelial cancer chemoprevention: how close we are to bedside? Toxicol Appl Pharmacol 2007, 224(3):350-359.

8. Kim KW, Choi CH, Kim TH, Kwon CH, Woo JS, Kim YK: Silibinin inhibits glioma cell proliferation via Ca2+/ROS/MAPK-dependent mechanism in vitro and glioma tumor growth in vivo. Neurochem Res 2009, 34(8):1479-1490.

9. Denizot F, Lang R: Rapid colorimetric assay for cell growth and survival. Modifications to the tetrazolium dye procedure giving improved sensitivity and reliability. J Immunol Methods 1986, 89(2):271-277.

10. Pastorino JG, Chen ST, Tafani M, Snyder JW, Farber JL: The overexpression of Bax produces cell death upon induction of the mitochondrial permeability transition. J Biol Chem 1998, 273(13):7770-7775.

11. Orrenius S, Zhivotovsky B, Nicotera P: Regulation of cell death: the calcium-apoptosis link. Nat Rev Mol Cell Biol 2003, 4(7):552-565.

12. Huang Y, Wang KK: The calpain family and human disease. Trends $\mathrm{Mol}$ Med 2001, 7(8):355-362.

13. Vanags DM, Porn-Ares MI, Coppola S, Burgess DH, Orrenius S: Protease involvement in fodrin cleavage and phosphatidylserine exposure in apoptosis. J Biol Chem 1996, 271(49):31075-31085.

14. Koivunen J, Aaltonen V, Peltonen J: Protein kinase C (PKC) family in cancer progression. Cancer Lett 2006, 235(1):1-10.

15. Musashi M, Ota S, Shiroshita N: The role of protein kinase $C$ isoforms in cell proliferation and apoptosis. Int J Hematol 2000, 72(1):12-19.

16. Gutcher I, Webb PR, Anderson NG: The isoform-specific regulation of apoptosis by protein kinase C. Cell Mol Life Sci 2003, 60(6):1061-1070.

17. Basu A, Miura A: Differential regulation of extrinsic and intrinsic cell death pathways by protein kinase C. Int J Mol Med 2002, 10(5):541-545.

18. Zhang HW, Yang Y, Zhang K, Qiang L, Yang L, Hu Y, Wang XT, You QD, Guo QL: Wogonin induced differentiation and G1 phase arrest of human U-937 leukemia cells via PKCdelta phosphorylation. Eur J Pharmacol 2008 591(1-3):7-12

19. Ogborne RM, Rushworth SA, O'Connell MA: Epigallocatechin activates haem oxygenase-1 expression via protein kinase Cdelta and Nrf2. Biochem Biophys Res Commun 2008, 373(4):584-588.

20. Gopalakrishna R, Jaken S: Protein kinase $C$ signaling and oxidative stress. Free Radic Biol Med 2000, 28(9):1349-1361.

21. Wu WS: The signaling mechanism of ROS in tumor progression. Cancer Metastasis Rev 2006, 25(4):695-705.

22. Frey RS, Gao X, Javaid K, Siddiqui SS, Rahman A, Malik AB: Phosphatidylinositol 3-kinase gamma signaling through protein kinase Czeta induces NADPH oxidase-mediated oxidant generation and NFkappaB activation in endothelial cells. J Biol Chem 2006, 281(23):16128-16138. 
23. Rahman A, Bando M, Kefer J, Anwar KN, Malik AB: Protein kinase Cactivated oxidant generation in endothelial cells signals intercellular adhesion molecule-1 gene transcription. Mol Pharmacol 1999, 55(3):575-583.

24. Birbes $H$, Bawab SE, Obeid LM, Hannun YA: Mitochondria and ceramide: intertwined roles in regulation of apoptosis. Adv Enzyme Regul 2002, 42 (113-129.

25. Gross A, McDonnell JM, Korsmeyer SJ: BCL-2 family members and the mitochondria in apoptosis. Genes Dev 1999, 13(15):1899-1911.

26. Green DR, Reed JC: Mitochondria and apoptosis. Science 1998, 281(5381):1309-1312.

27. Zou H, Henzel WJ, Liu X, Lutschg A, Wang X: Apaf-1, a human protein homologous to C. elegans CED-4, participates in cytochrome cdependent activation of caspase-3. Cell 1997, 90(3):405-413.

28. Chandra D, Liu JW, Tang DG: Early mitochondrial activation and cytochrome c up-regulation during apoptosis. J Biol Chem 2002, 52 (50842-50854.

29. Joza N, Susin SA, Daugas E, Stanford WL, Cho SK, Li CY, Sasaki T, Elia AJ, Cheng HY, Ravagnan L, Ferri KF, Zamzami N, Wakeham A, Hakem R, Yoshida H, Kong YY, Mak TW, Zuniga-Pflucker JC, Kroemer G, Penninger JM: Essential role of the mitochondrial apoptosis-inducing factor in programmed cell death. Nature 2001, 410(6828):549-554.

30. Otera H, Ohsakaya S, Nagaura Z, Ishihara N, Mihara K: Export of mitochondrial AIF in response to proapoptotic stimuli depends on processing at the intermembrane space. Embo J 2005, 24(7):1375-1386.

doi:10.1186/1756-9966-30-44

Cite this article as: Jeong et al: Silibinin induces apoptosis via calpaindependent AIF nuclear translocation in U87MG human glioma cell death. Journal of Experimental \& Clinical Cancer Research 2011 30:44.

\section{Submit your next manuscript to BioMed Central} and take full advantage of:

- Convenient online submission

- Thorough peer review

- No space constraints or color figure charges

- Immediate publication on acceptance

- Inclusion in PubMed, CAS, Scopus and Google Scholar

- Research which is freely available for redistribution

Submit your manuscript at www.biomedcentral.com/submit
Biomed Central 